\title{
Ideological Boundary-Making: Representing Immigrants in an Anti-Immigration Party
}

\author{
Dina Bader* and Alexandra Feddersen * *
}

\begin{abstract}
How can migrant organisations affiliated to anti-immigration political parties reconcile their party's ideology with the representation of immigrants? Based on a website content analysis, this article investigates the representative claims of a migrant group affiliated to the Swiss People's Party. Comparing them to the discourse of its left-wing counterpart, the findings show that the group sets ideological boundaries between immigrants, establishing a hierarchy that enables it to contrast its members with the immigrants targeted by its party. Keywords: Migrant organisations, radical right, representative claims, boundary-making, Switzerland
\end{abstract}

\section{Frontières idéologiques: représenter les immigré.e.s dans un parti anti-immigration}

Résumé: Comment un groupe de migrants affilié à un parti politique anti-immigration concilie-t-il l'idéologie de son parti avec la représentation des immigrés? Basé sur une analyse de contenu web, cet article analyse comment un groupe de migrants affilié à l'Union Démocratique du Centre déclare les représenter. En comparant son discours à celui de son homologue de gauche, les résultats montrent que le groupe établit des frontières idéologiques entre migrants, créant une hiérarchie lui permettant d'éloigner ses membres des migrants ciblés par son parti.

Mots-clés: Organisations de migrants, droite radicale, déclarations de représentation, frontières, Suisse

\section{Ideologische Grenzziehung: Repräsentation von Migrantinnen in einer migrations- feindlichen Partei}

Zusammenfassung: Wie können Migrantengruppen, die einer migrationsfeindlichen Partei angehören, die Ideologie ihrer Partei mit der Vertretung von Migranten vereinbaren? Dieser Artikel untersucht mittels einer Webinhaltsanalyse, wie eine Gruppe nahe der Schweizerischen Volkspartei erklärt, Migranten zu vertreten. Ein Vergleich mit dem Diskurs ihres linken Pendants zeigt, dass die Gruppe zwischen Migranten ideologische Grenzen zieht und damit eine Hierarchie bildet, die ihr die Distanzierung ihrer Mitglieder von Migranten ermöglicht, auf die ihre Partei abzielt.

Schlüsselwörter: Migration, rechtsradikale Parteien, Repräsentationsansprüche, Grenzen, Schweiz

* Sociology Department, New York University, NY-10012-9605 New York, dina.bader@nyu.edu

** Département des sciences de la communication et des médias, Université de Fribourg, CH-1700 Fribourg, alexandra.feddersen@unifr.ch 


\section{$1 \quad$ Introduction $^{1}$}

Migrant associations in civil society are often organised along ethnic, cultural or linguistic lines. These forms of migrant organisations have been extensively analysed, with studies investigating everything from their role in immigrants' political engagement to why immigrants join these groups in the first place (e.g., Morales and Giugni 2011; Morales and Ramiro 2011; Portes and Fernandez-Kelly 2015; Pilati and Morales 2016). Thus far, however, much less is known about migrant organisations that are either formally or informally affiliated to a political party. Since the 1980s, several such organisations have emerged in Western Europe, either as official intra-party groups, or with the intention of supporting a specific party (Martiniello 2009). In contrast to ethnic migrant organisations, which claim to represent a specific demographic group based on shared ethnic or cultural characteristics, party-affiliated migrant organisations aim to connect constituencies from different ethnic and cultural backgrounds on the basis of a shared political ideology, in an analogous way to party-affiliated women's organisations (e.g., Childs and Kittilson 2016).

Party-affiliated migrant organisations have emerged across the entirety of the ideological spectrum, including in support of anti-immigration parties ${ }^{2}$. This raises the question of how such organisations reconcile their claim to represent immigrants (and their descendants) ${ }^{3}$ with the political ideologies of their associated parties. In an attempt to tackle this question, this article examines the case of the Swiss migrant organisation Neue Heimat Schweiz, which supports the right-wing anti-immigration Swiss People's Party, and the ideologically opposed SP-MigrantInnen, an official group of the Social Democratic Party.

Drawing on a detailed website content analysis, our results indicate that political ideologies have strongly affected both of these organisations' representative claims. While the left-leaning group, SP-MigrantInnen, claims to represent all immigrants residing in Switzerland, the right-leaning group, Neue Heimat Schweiz, has set clear boundaries to its representative claims, declaring itself to be advocating only on be-

1 The authors are grateful to Leonie Mugglin, the editors of this Special Issue and the two anonymous reviewers for their helpful comments. An earlier version of this paper was presented at the 2019 ECPR General conference in Wroclaw. We would like to thank Alexandre Paturel for editing and proofreading. The research was funded by the Swiss National Science Foundation as part of the project "An Improbable Commitment? Explaining Naturalized Citizens' Political Engagement in the Swiss Social-Democratic Party and the Swiss People's Party" (grant 178840).

2 These parties may be either right-wing populist or radical-right populist (for a comprehensive definition see Mudde 2007). Since, for the purposes of this article, the distinguishing feature of these parties is their hostility towards immigration, we will refer to them here as anti-immigration parties. However, this by no means entails that right-wing (or radical-right) populist parties are the only anti-immigration parties in Western Europe. That said, anti-immigration rhetoric remains a defining characteristic of this type of party (Mudde 2007).

3 By immigrants and their descendants, we are referring both to naturalised citizens and non-Swiss residents. 
half of those immigrants who have "successfully" integrated into their host society. To reconcile its claim to represent immigrants with the anti-immigration agenda of the Swiss People's Party, Neue Heimat Schweiz has therefore deployed a strategy we call ideological boundary-making. We argue that this has enabled Neue Heimat Schweiz to position its constituents at the top of a discursive hierarchy within the migrant population, thereby distancing them from those migrants targeted by the Swiss People's Party's discourse and policies. In theorising the strategy of ideological boundary-making, this article provides a theoretical and empirical contribution to the overlooked social phenomenon of migrant political organisations affiliated to anti-immigration parties, as well as to the study of these parties' appeal to immigrant activists and voters.

\section{Theoretical Framework}

\subsection{Migrant Political Organisations}

Notions of political quiescence or migrant passivity have been historically prominent in the social scientific literature on European immigrants. As Martiniello (2009, 35-36) notes, immigrant workers "were not considered to be potential citizens" and were thus not "expected to be politically active". Notwithstanding this academic blind spot, as a matter of fact immigrants who came to Western Europe in the 1950s and 1960s often participated in trade union activity, while the next generation became increasingly involved in party politics (Martiniello 2009). In the 1980s, migrant political organisations - to be understood here as structured or organised migrant groups inside of, or affiliated to, established political parties - emerged in Western Europe. Sewell's (1993) subsequent seminal study of the black section of the British Labour Party in the 1980s lay the groundwork for research on these party-affiliated and intra-party migrant organisations.

However, the scarce research since carried out on these types of migrant organisations has largely focused on investigating their role in migrant political representation, as well as their implications for the political parties themselves. Broadly speaking, this research has found that, in addition to the standard functions carried out by most other party-affiliated organisations - for example, membership recruitment, leadership formation, and so forth - migrant organisations additionally fulfil four key purposes. Firstly, they form gateways into political participation for immigrants, since parties are gatekeepers of the access to institutional politics and conventional political participation (Michon and Vermeulen 2013). As such, migrant political organisations are "welcoming forums", which "function as first points of contact and/or 'safe spaces' for party members with migration background and/or (potential) party members interested in migration and integration policy" (Markard and Dähnke 2017, 817). Secondly, as Laurence and Maxwell (2012, 
24-25) underline, migrant organisations often work both to communicate the parties' "friendliness to voters with an immigrant background", as well as to serve as their "de facto spokespeople [...] on integration issues". Thirdly, they may allow for better coordination of immigrant party members, while also enabling the latter to have greater leverage when addressing shared demands on the party. Finally, they can act as "watchdogs" over party policies regarding immigrants and immigration writ large (Wauters et al. 2018).

As discussed in the context of intra-party women's groups (e.g., Childs and Kittilson 2016), the notion of substantive representation thus constitutes the basis of these intra-party or party-affiliated migrant organisations. Substantive representation here refers to representation "acting in the interest of the represented, in a manner responsive to them" (Pitkin 1972, 209). The aim of such groups is therefore not merely to give more visibility to party members identifying with a specific demographic, but furthermore to enable the party to deliver a more substantive representation of that demographic (Wauters et al. 2018).

\subsection{Political Ideology and Multicultural Conservatism}

Scholars studying migrant political organisations have found that migrant organisations are affiliated to political parties across the ideological spectrum. In the UK, for example, this has been true of both the Labour and Conservative parties since the early 1980s (Sewell 1993; Shukra 1998). In Germany, almost every party has an affiliated migrant organisation, for example the Arabische Sozialdemokraten, Immigrün, Deutsch-Türkisches Forum and Liberale Deutsch-Türkische Vereinigung (Laurence and Maxwell 2012). Thus, while existing research indicates that left-wing parties are generally more open to immigrants (e. g., Carvalho and Ruedin 2018), and correspondingly receive more support from immigrant voters (e.g., Michon and Vermeulen 2013), parties on both the left and the right have immigrant members, and try to appeal to immigrant voters and candidates (e.g., Burchianti and Zapata-Barrero 2017).

Left-leaning parties are generally considered "the most important ally for migrants" in institutional politics (Giugni and Passy 2006, 198). This reputation may be due to how these parties emphasise "egalitarian policies and social justice targeting the marginalized" (Wauters et al. 2016, 6). In the German case, for example, Schönwälder (2012) finds that the Greens and the Social Democrats explicitly mention their willingness to include more immigrant members in their election programs, while Burchianti and Zapata-Barrero (2017) come to similar conclusions in the Spanish context. In Switzerland, Strijbis' (2014) findings indicate that the Social Democratic Party is clearly preferred by many immigrant citizens, notably as the party mobilises a more liberal discourse on immigration (see also Ruedin 2013). However, as Strijbis (2014) also highlights, the Swiss People's Party (currently the largest party in the Swiss legislature), is the second most appealing 
party for immigrant voters. This may seem surprising, as the Swiss People's Party is what Mudde (2007) would call a "populist radical right party", which promotes a conservative and anti-immigration agenda (Ruedin 2013). Yet, this case exemplifies a more general trend, according to which right-wing parties seek to appeal to immigrant voters and candidates, even as they pursue restrictive immigration policies and entertain explicitly xenophobic discourses. For example, Bird and colleagues (2010) demonstrate that right-wing parties in Canada were sometimes more likely to bring up ethnic minority-related issues than their left-wing counterparts. In fact, as Burchianti and Zapata-Barrero $(2017,842)$ note, right-wing parties often "oppose the idea that advocating for a restrictive policy on immigration means that they are less inclined to include immigrants in their ranks".

At first glance, the commitment of racial or ethnic minorities to right-wing parties that overtly express racist or xenophobic views appears puzzling. In the American context, Dillard (2001) argues that members of the Republican Party who come from minority backgrounds are what she calls "multicultural conservatives". 4 Namely, they reject the identity politics commonly associated with the left, as well as the corresponding victimisation of minority groups. By contrast, they support notions of sameness, patriotism and "national" values (Dillard 2001, 77). Moreover, they campaign against state intervention in the realm of structural inequalities and believe in "the redemptive possibilities of assimilation, individualism, and character" (Dillard 2001, x). Conducted twenty years ago, Dillard's study demonstrates that the participation of minority groups in the political right is by no means a new phenomenon. Nevertheless, scholarship on this "improbable" relationship is scarce and predominantly North American (see also Prisock 2018). Moreover, existing research has not yet addressed how multicultural conservatives, inside or affiliated to anti-immigration parties, claim to represent their fellow citizens. Meanwhile, it is only by studying the political engagement of these rather unusual supporters of the political right that the full complexity of migrant political organisations may be further theorised.

\subsection{Representation and Boundary-Making}

According to Saward (2006, 305), political actors make representative claims when they purport "to represent or to know what represents the interests of someone or something". Defining who or what is represented thereby entails establishing boundaries between those who are represented and those who are not. "Boundarymaking" is the process of creating political groups by defining these representative limits (Wimmer 2013; Duemmler and Dahinden 2016). At the same time, such boundaries are fluid, and remain strongly related to the political projects that give

$4 \quad$ Following Dillard (2001), the term "multicultural" here refers to the diversity of subject positions within the mainstream conservative party, and not their (acknowledged lack of) support to multiculturalism. 
rise to them. Drawing on Tajfel and Turner $(1986,15)$, we understand a group in this context to be a "collection of individuals who perceive themselves to be members of the same social category, share some emotional involvement in this common definition of themselves, and achieve some degree of social consensus about the evaluation of their group and of the membership in it". To the extent that groups rest on self-established criteria and perceptions of sharedness, they are constituted by fundamentally "symbolic" boundaries (Lamont and Molnár 2002).

This definition, we contend, is what may best explain the particularity of migrant political organisations in relation to ethnic or cultural migrant organisations. Migrant political organisations connect persons from different backgrounds for the sake of a shared political goal. Drawing on Putnam (2000, 22), they may therefore be described as "bridging" associations - that is, groups or networks "encompassing people across diverse social cleavages". As such, they differ from ethnic minority associations, which reinforce "exclusive identities" (Putnam 2000, 22) by bringing together persons of the same ethnic or cultural background (see also Bird et al. 2010). The nature of Putnam's (2000) clear-cut distinction between "bridging" and "bonding" associations is, admittedly, ideal-typical, and most existing organisations will be located between these categorisations. However, as of yet, the research on migrant political organisations has not clearly defined how they differ from other migrant groups. Putnam's theory enables researchers to highlight how migrant political organisations are constituted beyond any set of cultural or ethnic characteristics. Sharing a similar background (here, a migration experience) does not per se bring all individuals together. Uncovering the process of boundary-making in group formation is thus crucial for understanding how migrant political organisations inside of, or affiliated to, political parties may challenge any conception of "immigrants" as forming a homogenous demographic with a correspondingly uniform political representation.

\section{Data and Methods}

Investigating party-affiliated migrant organisations in Switzerland is particularly meaningful. The country has a long-established community of immigration and foreign nationals, who together represent approximately a quarter of the population (OFS 2019). According to the Migrant Integration Policy Index (MIPEX 2015), Switzerland is among the countries in which it is hardest for foreign nationals to become citizens (ranked 31 out of 38). However, Switzerland does permit a degree of political participation to immigrants (ranking 12 out of 38 on the same index), especially for the residents of cantons or municipalities that grant voting rights to 
foreigners at the local level. ${ }^{5}$ Against that backdrop, the political representation of immigrants (whether naturalised or not) is a crucial question, as it is one of key ways in which immigrants can safeguard their political participation. Given Switzerland's multiparty system, several parties across the political spectrum may appeal to immigrants. This makes the commitment of a migrant group to a radical-right party with an anti-immigration agenda particularly noteworthy. To answer our research questions, we have focused on the case of the migrant group Neue Heimat Schweiz, which is affiliated to the Swiss People's Party. At the same time, for the purpose of a comparative analysis, we have selected an ideologically opposed migrant group, the left-leaning SP-MigrantInnen. In having selected Neue Heimat Schweiz and SPMigrantInnen, we examine the migrant organisations affiliated to the two leading political parties in Switzerland ${ }^{6}$ and preferred parties of immigrant voters and their descendents, as mentioned earlier.

Neue Heimat Schweiz and SP-MigrantInnen were created at around the same period (2010 and 2012 respectively), and their members' typical profiles are also similar. Both organisations include the first and second generations of a wide range of mostly underrepresented nationalities among immigrants in Switzerland ${ }^{7}$ (notably from Turkey, Kosovo and former-Yugoslavian countries, among many others). However, unlike SP-MigrantInnen, which is a national section of the Social Democratic Party, Neue Heimat Schweiz is not officially part of the Swiss People's Party. Nonetheless, several factors suggest a close connection between Neue Heimat Schweiz and the Swiss People's Party, enabling us to compare the former to standard party-affiliated groups. Firstly, the founder of Neue Heimat Schweiz, Yvette Estermann, is a Swiss People's Party national councillor (member of parliament), while the chair of the Zug section, Niko Trlin, is a party candidate. Secondly, the chair of the Basel section, Jasna Milanovic, declared in a press interview with the newspaper Tageswoche 8 in July 2014 that she founded the cantonal subgroup following the suggestion of a party representative. Thirdly, elected representatives of the Swiss People's Party, including then party president Toni Brunner, attended Neue Heimat Schweiz's inaugural event, affirming its status as an accepted organisation. Finally, as our analysis of their website indicates, members of Neue Heimat Schweiz regularly attend events organised by the Swiss People's Party and collect signatures for its popular initiatives?

5 Switzerland being a federal state, a considerable amount of leeway is given to sub-national entities, notably the cantons.

6 The Swiss People's Party was credited with a $25.6 \%$ vote share during the 2019 national election, while the Social Democratic Party received $16.8 \%$ of the vote.

7 In 2018, the great majority of foreign residents in Switzerland were citizens of neighboring countries (e.g., Germany, France and Italy; OFS 2019).

8 Duong, Yen.11.07.2014. Ich finde die SVP nicht ausländerfeindlich. Tageswoche.

9 Popular initiatives are instruments of direct democracy that allow Swiss citizens to propose a total or partial amendment of the federal Constitution, subject to a vote of the Swiss people. They require the signature of 100000 citizens. 
To analyse the representative claims of Neue Heimat Schweiz and SP-MigrantInnen, we carried out a content analysis of their websites. ${ }^{10}$ This well-established methodology for the study of political groups hinges on an examination of their official statements, thereby yielding insights regarding their political ideology, the political demands that bring their members together, and the rationales for their political affiliations (see Gfeller and Jaggi 2001; Caiani and Parenti 2013; Krämer 2017). Meanwhile, websites are privileged platforms of investigation, as they function as virtual ports of entry into understanding how these groups address potential members while publicly defending their political positions.

To understand how these groups present themselves to the public, we examined the general design of their respective websites, including their featured pictures. We then collected all of the text published on both websites (including attached press interviews and electronic flyers ${ }^{11}$ ) - as of November 20, 2018 for Neue Heimat Schweiz, and December 31, 2018 for SP-MigrantInnen. ${ }^{12}$ To reconstruct the groups' representative claims, we drew on a codebook of 13 thematic codes, using sentences as units of analysis and allowing overlapping codes. We investigated the groups' collective identity (Melucci 1995) by looking at how they justify both their political affiliations as well as their reasons for mobilising the immigrant community (2 codes). We examined how they represent their members, immigrants more generally, the Swiss people and Switzerland as a country (4 codes). We also analysed how they discuss migration-related issues (e.g., integration, citizenship and state borders), and whether they make statements on other political issues, or if they remain focused solely on migration ( 2 codes). Moreover, we paid attention to the type of language (including metaphors and keywords) they employed ( 2 codes). Finally, we analysed how they narrativised their groups' history, including accounts of the lives and personal commitments of their featured members (3 codes).

\section{4}

\section{Neue Heimat Schweiz}

\subsection{A Political Commitment towards the Host Country}

Our analysis of the website of Neue Heimat Schweiz shows that the group's focus is Switzerland and its prosperity. The group's name - Neue Heimat Schweiz (meaning "New Home Country Switzerland") - clearly summarises its vision: Switzerland is

10 SP-MigrantInnen's website: https://www.sp-ps.ch/de/partei/sozialdemokratische-bewegung/spmigrantinnen; Neue Heimat Schweiz's website: http://www.neue-heimat.ch. We only considered the German version of the websites. For reasons of visibility, Neue Heimat Schweiz's website is available in several different languages (automatic online translations in 58 languages).

11 However, we excluded comments from the online guestbook of Neue Heimat Schweiz, as we could not confidently identify those that were written by members of the group.

12 The total length of content available on both websites, and subsequently included in our analysis, is 58 text pages for Neue Heimat Schweiz and 21 for SP-MigrantInnen. 
the country its members have chosen as their new home. The texts on the website frequently employ the pronouns "we" and "our" to emphasise its members' inextricable link to the country. Moreover, the website features several images of Swiss landscapes (e.g., flowers, lakes, mountains), as well as the Swiss Federal Railways. The latter is particularly noteworthy as, in the Swiss popular imagination, taking the train is a synecdoche for a typical Swiss life. It is therefore unsurprising that members of Neue Heimat Schweiz refer to it as they describe their integration: ${ }^{13}$

We are polite [and] decent. [We] work and pay taxes. We have a good education, or even an academic qualification. We speak the language perfectly and greet our fellow men. We don't fight, and we mediate when possible. We also travel by bicycle or train. We pay social security. We save and spend.

The images shown on the website draw on stereotypes of Switzerland as a calm, efficient and punctual country. As the above quote demonstrates, the members of Neue Heimat Schweiz depict themselves in the same way. These qualities purport to demonstrate their "successful" integration, indeed assimilation, into Swiss society. In this vein, the group states:

We, the well-integrated immigrants [...] are here to fight for a safe, clean and successful Switzerland!

Neue Heimat Schweiz similarly understands these immigrants' commitment to their "new home" as a sign of proper integration, and in fact, the very goal of their organisation. On that basis, they seek to appeal to immigrants who share the same commitment, declaring:

Well-integrated foreigners who stand up for the values of Switzerland are cordially invited to participate in the association.

As this excerpt suggests, Neue Heimat Schweiz claims to represent those immigrants who meet their normative criteria. As such, the group clearly draws a boundary between "bad" and "good" immigrants, defining itself as representing solely the latter category rather than all individuals on the mere basis of a shared experience of migration. Put differently, it aims to appeal only to those immigrants who have demonstrated their "worthiness" by integrating into the host society.

\subsection{Integration as a Set of Duties}

In line with Dillard's (2001) theorisation of "multicultural conservatives", members of Neue Heimat Schweiz espouse conservative values, economic liberalism, and patriotism. These form the core elements of Neue Heimat Schweiz's definition of integration, while also placing them in line with the Swiss People's Party's stances on migration and the economy. In particular, the group has a behavioural concep-

13 All the following quotes were translated from German. 
tion of integration, understood as an individual's choice to fulfil specific duties. Their website's title therefore reads "Integration can be easy!" (Integration kann einfach sein.). This statement suggests that being integrated (or not) is a matter of individual choice (kann); one decides to fulfil the duties that integration requires. Correspondingly, Neue Heimat Schweiz overlooks institutional obstacles to integration, such as the barriers to entering the labour market faced by persons from an asylum background (Bertrand 2019).

Our content analysis suggests that Neue Heimat Schweiz highlights four duties in particular. The first is learning the local language: "German is a duty!" (Deutsch is Pflicht:). Neue Heimat Schweiz makes clear in its rhetoric that linguistic proficiency preconditions integration. For example, it regularly blames immigrant parents for having insufficiently developed their children's linguistic skills.

The second duty is contributing to Swiss economic prosperity. According to Neue Heimat Schweiz, immigrants should serve the interest of their host country not the other way around. For that reason, the group declares its support for migration strictly as an instrument of economic growth. As the founder of Neue Heimat Schweiz commented, with regard to Turkish immigrants:

I meet many well-integrated women and men who care about the well-being of the country. Whether they are employees or entrepreneurs, they will help ensure that Switzerland continues to be a common, successful home for us.

The third duty incumbent on immigrants is respecting Swiss traditions. Neue Heimat Schweiz - whose members are sometimes shown on their website wearing the Swiss folk dress during social events - depicts Switzerland as having a unique and singular identity. The group associates this identity with the values of neutrality, democracy and independence, while also portraying it as fundamentally Christian:

We want to protect and preserve Swiss traditions. Whoever comes to Switzerland must accept the laws, the state symbols and our traditions. Switzerland has a Christian tradition, and the flag with the cross belongs to Switzerland.

Notions of diversity and multiculturalism are accordingly absent from the vocabulary of Neue Heimat Schweiz. For example, when in 2011 another immigrant association called Second@s Plus called into question their image of an (exclusively) Christian Switzerland, the group responded by declaring:

The immigrant association 'Second@s Plus' demands the abolition of the Swiss cross! How disrespectful! [...] This group disturbs the religious peace in our country, disregards its worldwide respected symbol and is, therefore, a danger to our society! What is next? The abolition of Christian churches in Switzerland? 
As this quote indicates, Neue Heimat Schweiz sharply distinguishes between "good" immigrants, who respect Swiss values and traditions, and "bad" immigrants, who allegedly disrespect them by defending multiculturalism.

The fourth duty is respect of Swiss rules. Neue Heimat Schweiz declares this duty is critical to ensuring Switzerland's security. In this context, allusions to "bad" immigrants refer primarily to criminals. Although the group often points out that only a minority of immigrants have committed criminal acts, it nevertheless highlights foreign criminals as a significant problem, and is vocally in favour of their deportation. ${ }^{14}$

Those who abuse their right to hospitality, who do not abide by the rules and become criminals have to leave the country.

In this quotation, the use of the term "right to hospitality" (Gastrecht) demonstrates Neue Heimat Schweiz's argument that immigration is not a right. As the chair of the Zug section declares: "To be a guest is a privilege". In this context, the group perceives immigrant criminality as not only a sign of a lack of integration, but also as a mark of disrespect towards Switzerland's generosity. The website explains:

Neue Heimat Schweiz is clearly in favour of stricter laws for those who do not respect the norms and laws of Switzerland, even though Switzerland is one of the countr[ies] with the most progressive policies in the world and offers excellent basic conditions to all.

In this passage, Neue Heimat Schweiz explicitly suggests that Switzerland is already doing enough for immigrants and that, therefore, the latter should be grateful for what they have. This constitutes a veiled criticism of the left-wing migrant organisation SP-MigrantInnen, which calls on the Swiss state to do much more in the way of helping immigrants to integrate. By emphasising the need for gratitude, Neue Heimat Schweiz suggests that the social settings for one's individual integration are already established, and that collective claims for better conditions of integration are therefore inappropriate. This is in line with Dillard's $(2001,67)$ theorisation of multicultural conservatives as urging "self-help within communities".

\subsection{Exclusion in the Name of the Country's Prosperity}

Members of Neue Heimat Schweiz share a meritocratic understanding of migration, which explains their emphasis on the individual responsibility of immigrants to integrate. For them, the right of immigrants to remain in Switzerland depends on the positive contribution of each individual to the country. On this point, the

14 Neue Heimat Schweiz supported the popular initiative entitled "For the effective deportation of foreign criminals (implementation initiative)". This initiative, launched by the Swiss People's Party and rejected by Swiss citizens in 2016, called for the deportation of all foreigners convicted of committing specific offences listed by the initiative. 
group's support for the deportation of "criminal” immigrants enables its members to distance themselves from the Swiss People's Party's other immigrant targets. This is what the group means when it states that not all immigrants should be placed "in the same pot". Convinced that foreign criminals damage the reputation of all the "good" immigrants, Neue Heimat Schweiz's members declare that:

A greater help for us immigrants, secondos [i.e., children of immigrants], and foreigners would be to finally end the lenient penalty system and start the consistent deportation of criminals. This would release us from being the hostages of our 'compatriots', who harm society, disobey the law and thus stain the reputation of righteous foreigners.

Meanwhile, the group labels asylum seekers "economic refugees" (Wirtschaftsflüchtlinge) by defining their primary motivations for immigrating to Switzerland as economic ones, rather than political ones. Such an argument would qualify these asylum seekers as "bogus" refugees, according to the 1951 UN Refugee Convention. Neue Heimat Schweiz thereby also establishes boundaries to asylum seekers, advocating for them to be barred entry into the country:

In terms of surface area and population, Switzerland occupies a leading position worldwide in the welcoming of refugees. However, even with the best will, it cannot take in the 'whole world'. The attractiveness of our country as an asylum country must be radically reduced! This will reduce the number of deaths and the population can finally breathe a sigh of relief.

Nevertheless, just as the group claims to reject immigrants who allegedly seek to exploit Switzerland economically, it claims to welcome those immigrants who stand to contribute to the country's economic prosperity (itself one of Neue Heimat Schweiz's primary objectives). Indeed, it calls wealthy foreigners "a financial blessing for our country". On these grounds, in 2014 it vehemently opposed a left-wing initiative in Zurich proposing to abolish the flat-rate tax for wealthy foreigners. ${ }^{15}$

In the end, Neue Heimat Schweiz claims that stricter immigration control is necessary to protect Switzerland. As the chair of the Basel section stated in a press interview printed on the website:

[...] they [my parents] are also grateful that they can be in Switzerland. Nevertheless, I think a limitation [of immigration] makes sense. Immigration used to be more regulated - and that was a good thing.

As this extract demonstrates, members of Neue Heimat Schweiz affirm the state's right to select the foreigners on the basis of their "worthiness". In return, immigrants

15 The initiative titled "End of tax privileges for millionaires (abolition of flat-rate taxation)" was supported by several left-wing groups, including the Social Democratic Party and the Greens, and rejected by the Swiss citizens on November 2014. 
are called on to express their gratitude towards the Swiss state and people. Adopting such a meritocratic view of migration enables them to overcome what otherwise seems like a contradiction between their political stances on immigration and their own personal backgrounds as members of the immigrant community.

\subsection{Meritocracy and the Denial of Anti-Immigration Politics}

Given their meritocratic understanding of migration, their hierarchical classification of the immigrant population, and their claims to represent "good" immigrants, members of Neue Heimat Schweiz do not consider their political affiliation with the Swiss People's Party to be paradoxical. Instead, the group declares that their party "is committed to 'integrated foreigners' and naturalised persons". As the chair of the Basel section argues:

I do not think the SVP [Swiss People's Party] is xenophobic; it is just honest and direct [...]. In the media, the party comes across as being much stricter than it is. So far, I have only had good experiences with SVP people. [...] But if I were to perceive xenophobia in the SVP, I would have trouble getting involved with the association, because then I would feel uncomfortable.

Thus, Neue Heimat Schweiz rejects the idea that racism may influence anti-immigration politics. In the words of the chair of its Zug section:

For years, we secondos [children of immigrants], immigrants and foreigners, have been told that other people here hate us and do not like us at all. [...] The Swiss [...] are not racists. They just do not want the flowers in their garden to be trampled on. They just want to be treated with respect, and the Swiss laws and customs to be recognised and appreciated. They want to drink their coffee in peace, without someone spitting continuously in it. They just want to keep what makes their lives so worth living. Wouldn't everyone want that? Is it inhumane to want to mind one's own business? Or is it even racist?

This quote demonstrates what Boulila (2019) calls "racial denial", a phenomenon whereby racism is merely understood as existing in inter-personal relations, but not within broader structures. Likewise, Neue Heimat Schweiz rejects the assumption that Switzerland could intentionally discriminate against immigrants. Rather, the group's meritocratic view of integration and boundary-making within the immigrant population enables it to explain the lack of substantial equality for immigrants in Switzerland as being due to personal misdemeanours of individuals.

Moreover, far from understanding nationalist rhetoric as being potentially xenophobic, it perceives it to be inclusive of foreign residents. As the group declares:

[The right] defends its people, including us foreigners, [...]. The better this country is doing, the better we - being a part of it - do too. 
Such a line of reasoning exemplifies how, by overlooking the discriminatory component of anti-immigration politics, Neue Heimat Schweiz can reconcile its representative claims with the Swiss People's Party's overtly nationalistic agenda.

\section{SP-Migrant/nnen}

\subsection{A Political Commitment towards Immigrants}

While Neue Heimat Schweiz emphasises that the well-being of Switzerland may be furthered by its immigrant residents, SP-MigrantInnen centres that the well-being of immigrant residents may be furthered by the Swiss welfare state. The group's intended constituents and beneficiaries are clear from its name - immigrants (MigrantInnen). SP-MigrantInnen states its objective as "the equality of all immigrants in the social, political, economic, and cultural spheres, as well as the implementation of human rights and the prevention of discrimination against immigrants". The frequent repetition of the term "all" in SP-MigrantInnen's discourse is testament to how the group positions itself as the voice of every individual sharing a migration background, regardless of their individual "performance" in the integration process. From the point of view of its representative claims, there are therefore no "good" and "bad" immigrants.

\subsection{Integration as a Set of Fights}

SP-MigrantInnen stresses integration as a collective responsibility. This is not least as, from its point of view, integration is impossible without a degree of state provision to tackle existing structural barriers. SP-MigrantInnen makes this argument on the basis of fairness - specifically by helping immigrants as they contribute to the Swiss economy. As its website states

We want to distribute the prosperity we have reached together more fairly.

Switzerland is strong when everyone is well-not just a few.

Accordingly, the group understands integration as a process entailing access to a set of rights. Firstly, the "equality" to which it is committed goes beyond equality before the law, emphasising notions of substantive equality: that immigrants should have access to social goods such as housing, employment and training.

Secondly, the group advocates for equality between religions, refuting Neue Heimat Schweiz's Christian-centric portrayals of Switzerland. This is exemplified by the following statement:

With the recognition [of a religious community], the canton also gains a contact partner, such that the critical needs of non-Christian communities can be satisfied on equal terms with those of the major Christian confessions. 
Thirdly, SP-MigrantInnen supports the right of immigrants residing in Switzerland to express themselves politically, notably by being given the right to vote. Here, it draws parallels between nationality-based and gender-based prohibitions of political participation:

We, the SP-MigrantInnen, demand full political rights for all those who have settled in Switzerland. It is unacceptable that, to this day, Switzerland excludes a quarter of the population - more than two million people - from democratic participation and deprives them of the right to vote. This equals the scandal of when the Swiss federal state, founded in 1848, refused half the population - the women - their political rights until 1971.

Accordingly, with the hope of increasing the political participation of immigrant voters, SP-MigrantInnen provides translations of national direct democratic votes:

To allow as many immigrants as possible to read about the initiative in their mother tongue, we have printed flyers in eleven languages.

These translations also operate as a symbolic means of inviting non-Swiss citizens into active political participation. In a similar vein, SP-MigrantInnen has translated its call for immigrants to demand Swiss citizenship into several languages. Taken together, these actions suggest that, from SP-MigrantInnen's point of view, linguistic skills should not be a prerequisite for full political rights. This challenges the legal stipulation that the ability to speak one of the four national languages is a precondition of both Swiss citizenship and the right to vote at the federal level. ${ }^{16}$

\subsection{Inclusion in the Name of the Country's Prosperity}

SP-MigrantInnen champions a civic conception of citizenship in which being a citizen is defined by one's participation in, and acceptance into, the host society, rather than by a mere administrative decision bestowing an individual with a passport. This is shown by how the group refers to immigrant citizens as "Swiss of migratory origin", and immigrant non-citizens as "Swiss without a passport". As it states clearly:

Over two million inhabitants have no Swiss passport. They live here, they go to school with us, they play football with us or go swimming with us, they work with us, they pay taxes - they belong to us, to Switzerland.

Just as it does not advocate for distinctions to be made within the immigrant population, SP-MigrantInnen rejects all hierarchies normatively differentiating Swiss and non-Swiss citizens. As it states:

We, immigrants, are not second-class people. We belong to the Swiss society like everyone else. We contribute to Switzerland's prosperity and well-being

16 The prohibition only applies to national issues, as some cantons such as Geneva and Neuchâtel give foreign residents the right to vote on cantonal matters. 
through our work, taxes and social security contributions. We enrich the culture through the diversity of our languages, experiences and global networks.

The frequent use of the word "diversity" further illustrates the group's inclusive definition of Swiss national identity. This is reflected in SP-MigrantInnen's statements regarding the Swiss National day:

On August $1^{\text {st }}$. Switzerland's diversity will once again be addressed in the official speeches. And rightly so, because Switzerland has always distinguished itself through its different languages, cultures and religions.

As such, SP-MigrantInnen emphasises Switzerland's pluralistic and multicultural history as the proper backdrop to the contemporary inclusion of residents from different backgrounds. Nonetheless, the group also advocates for this inclusion on the basis of the country's general prosperity. For this reason, it declares that immigration is "advantageous for Switzerland for many reasons":

Without immigration, entire economic sectors, as well as the education and social systems, would already be in great difficulty today. SP-MigrantInnen stands up for a policy that emphasises the opportunities of migration, and helps to reduce and distribute the costs and risks associated with migration as fairly as possible. Problems that arise cannot be solved by exclusion and discrimination, but, on the contrary, require mutual respect and the willingness of all parties to cooperate.

Consequently, the group calls for an "open and positive attitude towards people who want to spend their lives in Switzerland". In this quote, SP-MigrantInnen uses the verb "want" (wollen) to plead for the welcoming of those who have chosen Switzerland as their country of residence. In this respect, its language differs sharply from Neue Heimat Schweiz, which argues that immigrants have been "allowed" (dürfen) to live in Switzerland. This is because, unlike its right-wing counterpart, SP-MigrantInnen does not champion a meritocratic understanding of migration. Instead, it conceives of migration as an inalienable human right.

\subsection{Social Justice and the Denial of the Party's internal Divisions}

Given SP-MigrantInnen's goal of safeguarding and furthering the rights conferred on immigrants, the group perceives the Social Democratic Party, to which it is affiliated, as the ideal "ally" for such social justice demands (Giugni and Passy 2006):

Always an advocate of social justice, the [Social Democratic Party] today counteracts the open or underhand attacks on people who are temporarily or permanently dependent on the social safety net. All those who suffer from poverty, hardship or social exclusion should be able to expect support and protection from the welfare state. Instead of stigmatising and excluding the 
socially weak, the problems must be tackled at their roots, and social cohesion must be strengthened.

As this quotation suggests, SP-MigrantInnen perceives their affiliated party as defending the most vulnerable in Swiss society. For the group, this includes immigrants who depend on public social security - precisely those Neue Heimat Schweiz would shun as being allegedly unable to contribute to Switzerland's economic prosperity.

That said, SP-MigrantInnen's image of the Social Democratic Party hides the internal divisions that have prevented the latter from always taking a clear stance on immigration (Ruedin and Morales 2019). As a matter of fact, the party's reputation of being opposed to nationality-based discrimination is relatively recent. Until the 1970s, and under the pressure of trade unions, it took a stand against open borders and viewed immigrants as a threat to Swiss employment. Meanwhile, it was the Swiss People's Party that pushed for economic liberalism. The positions of the two parties shifted in the 1990s when the Swiss People's Party adopted its winning formula, economic liberalism combined with cultural conservatism, while the Social Democratic Party adopted a more welcoming discourse towards immigrants (at least officially, and by no means unanimously).

All in all, our findings suggest that both SP-MigrantInnen and Neue Heimat Schweiz repackage their respective party's ambivalence towards migration into a purportedly univocal support for immigration (notwithstanding whether this support is extended towards all immigrants, or only the allegedly "good" ones). Each migrant organisation therefore presents the ideology of their affiliated party as being perfectly aligned with their representative claims.

\section{Conclusion}

This paper set out to investigate how a migrant organisation affiliated to a rightwing party could reconcile its representative claims with its party's anti-immigrant agenda. As of yet, little research had been conducted on this question, even though several studies have explored the question of immigrant support for right-wing parties more generally. To ground our own investigation, we adopted a comparative analysis, conducting a website content analysis of two opposed migrant organisations linked to the largest political parties in Switzerland respectively: Neue Heimat Schweiz, which is affiliated to the radical-right Swiss People's Party and SP-MigrantInnen, an official group of the Social Democratic Party.

Our findings indicate that the representative claims of Neue Heimat Schweiz were shaped by a process we have called ideological boundary-making. Specifically, the group has established ideological boundaries within the immigrant population, dividing it into "good" or "worthy" immigrants and "bad" or "unworthy" ones. Neue Heimat Schweiz positions its members at the top of the ensuing hierarchy, thereby 
distancing them from the Swiss People's Party's targets. By contrast, the left-wing migrant group draws no such distinctions, and claims to represent all individuals sharing an immigrant background.

Our analysis moreover shows that the use of this process of ideological boundary-making depends on two additional criteria. Firstly, ideological boundary-making depends on the migrant groups' definition of integration. For Neue Heimat Schweiz, integration consists of an individual fulfilling of a set of duties leading to assimilation in the host society. For SP-MigrantInnen integration is a societal responsibility, according to which a set of rights should be guaranteed by the state as a means of ensuring equality among all residents. Secondly, the migrant groups' respective perspectives on migration policies also play a crucial role. While both migrant groups acknowledge the presence of immigrants as being beneficial for Switzerland's prosperity, they differ on their stances on how to regulate immigration. Neue Heimat Schweiz calls for strict border controls and the exclusion of immigrants they consider to be unworthy of the host society, whereas their left-wing counterpart praises liberal immigration policies and advocates for the full inclusion of all immigrants.

Taken together, our results suggest that the affiliation of a migrant group to an anti-immigration party is not as "improbable" as it may seem. The right-wing group we examined shares its affiliated party's conservative values and political ideology of individualism, economic liberalism and nationalism. They have therefore aligned their representative claims accordingly. As such, our analysis empirically extends Dillard's (2001) theorisation of "multicultural conservatives" to the Swiss context. Furthermore, our findings challenge commonsensical assumptions according to which migrant political organisations are seen as "bridging" associations (Putnam 2000), which represent the immigrant population without distinction. In the case of our case study, this held true for only the left-wing SP-MigrantInnen. By contrast, the right-wing migrant group we examined operated more as a "welcoming forum" (Markard and Dähnke 2017) only for immigrants who are purportedly "successfully" integrated. This group draws ideological boundaries, bestowing its members with moral and political worth according to an elitist understanding of naturalisation as being a "reward" for demonstrating one's "contributions" to the economy.

This process of ideological boundary-making, we contend, is an indispensable prerequisite for a political migrant group affiliated to an anti-immigration party. Neue Heimat Schweiz supports the exclusion of certain immigrants because this simultaneously allows the group to embody an example of "successful" integration. For the party, the migrant group embodies "token" minority representatives (Prisock 2018). They enable the party to whitewash accusations of xenophobia and racism, and demonstrate that there is no contradiction between the inclusion of immigrant members and their political demands regarding immigration more broadly (Burchianti and Zapata-Barrero 2017). Moreover, the migrant group's meritocratic understand- 
ing of immigration allows the party to pretend to be "colorblind" (Prisock 2018), in favour of being "selective" in their appreciation of immigrants.

While our case study and theorisation of ideological boundary-making provide important empirical and theoretical contributions to the analysis of migrant organisations affiliated to the political right, more research needs to be undertaken concerning this neglected domain. In particular, while our study provides insights on the collective commitment of right-wing migrant groups, further qualitative research is needed to explore individual members' biographies and personal motivations for their engagement, particularly if and when immigrant members come from ethnic or cultural backgrounds that their party deem to be "unworthy". It is only by looking at all levels of analysis that we can understand this complex phenomenon.

\section{References}

Bertrand, Anne-Laure. 2019. Refugees' Trajectories in Switzerland: Impact of Residence Permits on Labour Market Integration. Quetelet Journal 7(1): 71-99.

Bird, Karen, Thomas Saalfeld, and Andreas M. Wüst (eds.). 2010. The Political Representation of Immigrants and Minorities: Voters, Parties and Parliaments in Liberal Democracies. Milton Park: Routledge.

Boulila, Stefanie. 2019. Race and Racial Denial in Switzerland. Ethnic and Racial Studies: 42(9): 1401-1418.

Burchianti, Flora, and Ricard Zapata-Barrero. 2017. From Participation to Confinement: Challenges for Immigrants' Incorporation in Political Parties in Spain. Ethnic and Racial Studies 40(5): 830-850.

Caiani, Manuela, and Linda Parenti. 2013. European and American Extreme Right Groups and the Internet. London: Routledge.

Carvalho, João, and Didier Ruedin. 2018. The Positions Mainstream Left Parties Adopt on Immigration: A Cross-Cutting Cleavage? Party Politics, online preview.

Childs, Sarah L., and Miki Caul Kittilson. 2016. Feminizing Political Parties: Women's Party Member Organisations Within European Parliamentary Parties. Party Politics 2(5): 598-608.

Dillard, Angela D. 2001. Guess Who's Coming to Dinner Now? Multicultural Conservatism in America. New York: NYU Press.

Duemmler, Kerstin, and Janine Dahinden. 2016. Gehören wir dazu? Grenzziehungsprozesse und Positionierungen der zweiten Generation im Vergleich zwischen Luzern und Neuchâtel. Schweizerische Zeitschrift für Soziologie 42(2): 309-331.

Gfeller, Maria, and Marco Jaggi. 2001. Die Schweizer Parteien im Internet: eine Modellstudie. Bern: Institut für Medienwissenschaft der Universität Bern.

Giugni, Marco and Florence Passy (eds). 2006. Dialogues in Migration Policy. Lanham, MD: Lextington Books.

Krämer, Benjamin. 2017. Populist Online Practices: The Function of the Internet in Right-Wing Populism. Information, Communication and Society 20(9): 1293-1309.

Lamont, Michèle, and Virág Molnár. 2002. The Study of Boundaries Across the Social Sciences. Annual Review of Sociology 28: 167-195.

Laurence, Jonathan, and Rahsaan Maxwell. 2012. Political Parties and Diversity in Western Europe. Pp. 13-31 in Immigrant politics: race and representation in Western Europe, edited by Terri E. Givens and Rahsaan Maxwell. Boulder, Colo: Lynne Rienner Publishers.

Markard, Lea, and Iris Dähnke. 2017. Contested Discourses on Diversity and Practices of Diversity Incorporation in Political Parties in Germany. Ethnic and Racial Studies 40(5): 809-829. 
Martiniello, Marco. 2009. Immigrants and Their Offspring as Political Subjects. Pp. 33-47 in Bringing outsiders in: transatlantic perspectives on immigrant political incorporation, edited by Jennifer L. Hochschild and John H. Mollenkopf. Ithaca: Cornell University Press.

Melucci, Alberto. 1995. The Process of Collective Identity. Pp. 41-63 in Social Movements and Culture, edited by Hank Johnston and Bert Klandermans. Minneapolis: University of Minnesota Press.

Michon, Laura, and Floris Vermeulen. 2013. Explaining Different Trajectories in Immigrant Political Integration: Moroccans and Turks in Amsterdam. West European Politics 36(3): 597-614.

MIPEX. 2015. Migrant Integration Policy Index. Available from: http://www.mipex.eu/ (04.05.2020)

Morales, Laura, and Marco Giugni (eds.). 2011. Social Capital, Political Participation and Migration in Europe: Making Multicultural Democracy Work? London: Palgrave Macmillan UK.

Morales, Laura, and Luis Ramiro. 2011. Gaining Political Capital Through Social Capital: Policy-Making Inclusion and Network Embeddedness of Migrants' Associations in Spain. Mobilization: An International Quarterly 16(2): 147-164.

Mudde, Cas. 2007. Populist Radical Right Parties in Europe. Cambridge: Cambridge University Press.

OFS. 2019. La population de la Suisse en 2018. Neuchâtel: Office fédéral de la statistique.

Pilati, Katia, and Laura Morales. 2016. Ethnic and Immigrant Politics Vs. Mainstream Politics: The Role of Ethnic Organisations in Shaping the Political Participation of Immigrant-Origin Individuals in Europe. Ethnic and Racial Studies 39(15): 2796-2817.

Pitkin, Hanna F. 1972. The Concept of Representation. Berkeley, Los Angeles: University of California Press.

Portes, Alejandro, and Patricia Fernandez-Kelly (eds.). 2015. The State and the Grassroots. Immigrant Transnational Organisations in Four Continents. New York: Berghahn.

Prisock, Louis G. 2018. African Americans in Conservative Movements: The Inescapability of Race. Palgrave Macmillan.

Putnam, Robert D. 2000. Bowling Alone. New York: Free Press

Ruedin, Didier. 2013. Obtaining Party Positions on Immigration in Switzerland: Comparing Different Methods. Swiss Political Science Review 19(1): 84-105.

Ruedin, Didier, and Laura Morales. 2019. Estimating Party Positions on Immigration: Assessing the Reliability and Validity of Different Methods. Party Politics 25(3): 303-314.

Saward, Michael. 2006. The Representative Claim. Contemporary Political Theory 5: 297-318.

Schönwälder, Karen. 2012. Cautious Steps: Minority Representation in Germany. Pp. 67-85 in Immigrant Politics: Race and Representation in Western Europe, edited by Terri E. Givens and Rahsaan Maxwell. Boulder, Colo: Lynne Rienner Publishers.

Sewell, Terr A. 1993. Black Tribunes: Black Political Participation in Britain. London: Lawrence Wishart.

Shukra, Kalbir. 1998. The Changing Pattern of Black Political Participation in Britain. London: Pluto Press.

Strijbis, Oliver. 2014. Migration Background and Voting Behavior in Switzerland: A Socio-Psychological Explanation. Swiss Political Science Review 20(4): 612-631.

Tajfel, Henri, and John C. Turner. 1986. The Social Identity Theory of Intergroup Behavior. Pp. 7-24 in Psychology of Intergroup Relation, edited by Stephen Worchel and William G. Austin. Chicago: Hall Publishers.

Wauters, Bram, Floor Eelbode, and Karen Celis. 2016. Parties Matter, Right? Parties as Actors for the Substantive Representation of Ethnic Minorities. Retrieved from Pisa: https://biblio.ugent.be/ publication/7197949/file/7197950 (18.06.2020).

Wauters, Bram, Floor Eelbode, and Karren Celis. 2018. Colorful or Colorless? Local Parties Defending Ethnic Minority Interests. Lex Localis 16(3): 413-430.

Wimmer, Andreas. 2013. Ethnic Boundary Making: Institutions, Power, Networks. Oxford: Oxford University Press. 